\title{
Improving Business Performance through Innovation Strategy and Total Quality Management Practice: Survey on the Pharmaceutical Industry in Indonesia
}

\author{
Yuli Fitriyani ${ }^{\mathrm{a}, *}$, Yudi Aziz ${ }^{\mathrm{a}}$, Irvan Rivani ${ }^{\mathrm{a}}$, Umi Kaltumª ${ }^{\mathrm{a}}$ John Sihotang ${ }^{\mathrm{a}}$ \\ ${ }^{a}$ Master of Management Program Faculty of Economics and Business, Padjajaran University, Indonesia
}

\begin{abstract}
The main purpose of this research is to analyze the relationship between innovation strategy and Total Quality Management (TQM) in improving business performance. The object of study of this research is the pharmaceutical Industries in Indonesia. This research reveals the proper innovation strategy execution and effective implementation of TQM in business performance improvement. In this context, data collected from 168 managers at 42 firms operating in the pharmaceutical industry in Indonesia were analyzed. The partial least squares structural equation modeling (PLS-SEM) method is used to test the hypotheses both of reflective and formative construct with second-order/higher-order construct in our model of study which is rarely found in the previous study. The findings support the hypothesis that there is a positive and significant effect of innovation strategy and TQM on improving the business performance of the company. The result of this research will have strategic implications for the company and expect to be used as feedback related to the execution of their innovation strategies and TQM implementation promptly to improve their business performance.
\end{abstract}

Keywords: innovation strategy, total quality management, business performance, strategic management happiness at work, work motivation, employee performance

\section{INTRODUCTION}

Today, the pharmaceutical industry in Indonesia is one of the priority sectors because it is considered to provide a significant contribution to the growth of the Indonesian economy. The pharmaceutical industry market grew $7.5 \%$ until the fourth quarter of 2016, higher than the same period in the previous year which was $4.9 \%$ (Kalbe Farma, 2018).

One of the driving factors for pharmaceutical industry growth is the widespread participation of the National Health Insurance (Jaminan Kesehatan Nasional/JKN) or BPJS (Badan Penyelenggara Jaminan Sosial kesehatan). JKN is health protection program provided by the Indonesian Government that covered basic health needs given to everyone who has paid contributions or fees paid by the government. This program aims to provide health insurance for all Indonesians and expatriates working in Indonesia for more than 6 months.

JKN program will continue to be the main driver for the development of the healthcare and pharmaceutical industries,

\footnotetext{
${ }^{*}$ Author in correspondence,

Email address: yuli17004@mail . unpad.ac.id (Yuli Fitriyani)
}

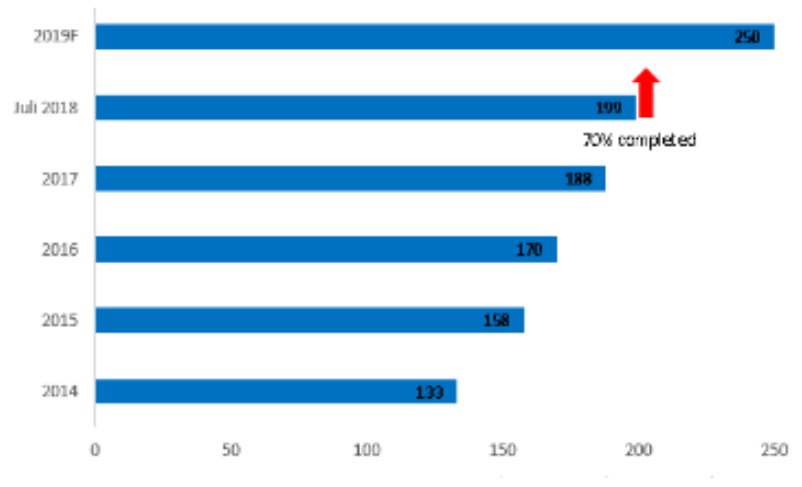

Figure 1: Pharmaceutical Industry Market in Indonesia, 2012-2016 Source: IMS Health, 2017 


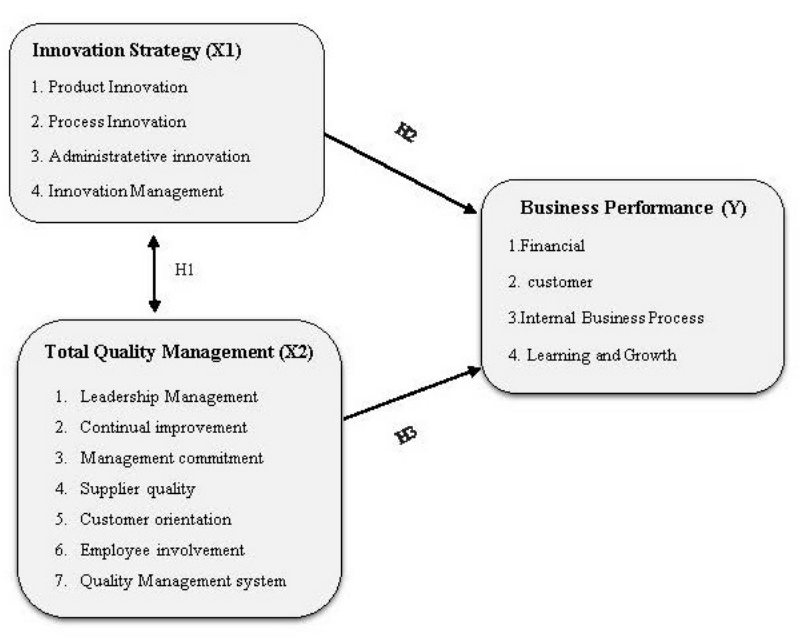

Figure 2: Growth of JKN Program Participants, 2014-2019 Source: BPJS, July 2018

where the health industries continue to record growth in the number of BPJS Kesehatan participants which reached around 199 million in July 2018. This is in line with the initial plan of the JKN program which targeted 100\% coverage in 2019 for the entire Indonesian population of 250 million.

Even though pharmaceutical industry growth is increasing, however, its growth in 2016 was lower compared to the compound annual growth rate (CAGR) growth in 2012-2016 worth $8.9 \%$. This is caused by the JKN implementation. In terms of quantity, medicine consumption has indeed increased, but sales have decreased, since most medicine used in JKN program was generic drugs which selling price has been set by the government through the Government Agency for Procurement of Goods and Services Policy, meanwhile the price is not negotiable. Some pharmaceutical industries in Indonesia face a slowdown in business growth. For example, PT Kalbe Farma Tbk, they experienced a slowdown in business growth from the 2014-2016 period reaching 14.7\%. However, in 2016-2017 the company's sales growth was only around 4.5\% (Kalbe Farma, 2018).

Most of the generic drugs sold under the JKN program are cheaper so that they cannot drive sales much higher for the company. Other causes are $90 \%$ of raw materials for medicine production originating from imports and high cost of distribution. Pharmaceutical companies must distribute their medicines to remote areas far from factories with the same selling price because they are participating in the JKN program. New challenges for the pharmaceutical industry in Indonesia in the JKN system implementation era are able to produce cheap medicines but still, the quality should be guaranteed. To obtain marketing authorization, medicinal products should meet the standards of quality, efficacy, and safety that have been determined in accordance with the regulation of Good Manufacturing Practices (GMP).

This phenomenon raises questions about key success factors related to the effectiveness of corporate strategies that must be implemented in order to survive and grow sustainably with the change in the business landscape of the pharmaceutical industry which is currently undergoing changes to the insurance market, namely producing generic drugs at low prices (low cost and low margin medicines). To overcome these challenges, while ensuring sustainable growth of the pharmaceutical industry in Indonesia, an innovation strategy in terms of research and development and industrial raw materials are needed as an opportunity for improving business in the pharmaceutical industries. Innovation can have a significant impact on the performance of a company's business through better market share, thus increasing the competitiveness of the company and ultimately will have an impact on improving its business performance. In today's competitive world, it is concluded that using old methods will not be efficient anymore. New technology and product innovation are some new techniques that are currently considered to be implemented globally in order to survive in the competition (Tohidi and Jabbari, 2012).

Innovation has played a significant role in creating unique products and services, in order to get value-added for the company and then determine constraints to entry for new rivals (Antunes et al., 2017). However, the company is impossible to get avail from the innovation advantages if there is no organizational structure that is deemed qualified to follow these strategies. Based on these reasons, innovation has triggered the interest of many researchers to identify the driving factors, and one of the problems that have been considered is whether the practice of TQM can emerge as one of the supporting factors of the innovation strategy. The intense global competition has had an impact on the development of TQM concept (Ahmad et al., 2012).

In the literature, it can be found opposite ideas, and that is why there is no consensus about whether innovation creates conditions for the application of TQM or TQM actually helps create an environment and culture to support innovation (Antunes et al., 2017). One of the goals of this research is to contribute in an enriching way to the study of these variables, based on Indonesian pharmaceutical companies. Thus, it is intended in this research to analyze the relationship between innovation strategy and TQM in improving business performance. Furthermore, we use both of reflective and formative constructs with second-order/higher-order construct in our model of study which is rarely found in the previous study.

The result of this research will have strategic implications for the company and expect to be used as feedback related to the execution of their innovation strategies and TQM implementation promptly to improve their business performance.

\section{LITERATURE REVIEW}

Several previous studies regarding the role of innovation strategy on the company's business performance showed a positive relationship between the two from various dimensions, for example, Al-Battaineh (2018) revealed that product innovation, process innovation, and innovation management had a positive influence on improving the company's business performance. Other researchers also argued that process innovation and product innovation have a positive impact on a company's 
Table 1: Sales Growth of Pharmaceutical Industries in Indonesia

\begin{tabular}{cllc}
\multicolumn{4}{c}{ Table 1: Sales Growth of Pharmaceutical Industries in Indonesia } \\
\hline No & Company Name & $\begin{array}{l}\mathbf{2 0 1 6 - 2 0 1 7} \\
\text { Growth }\end{array}$ & $\begin{array}{l}\mathbf{2 0 1 5 - 2 0 1 6} \\
\text { Growth }\end{array}$ \\
\hline 1 & PT Darya-Varia Laboratoria Tbk & $8.56 \%$ & $11.12 \%$ \\
2 & PT Kimia Farma (Persero) Tbk & $5.44 \%$ & $19.6 \%$ \\
3 & PT Kalbe Farma Tbk & $4.17 \%$ & $8.3 \%$ \\
4 & PT Industri Jamu dan Farmasi & $0.47 \%$ & $55.2 \%$ \\
& Sido Muncul Tbk & & \\
5 & PT Tempo Scan Pacifik Tbk & $4.68 \%$ & $11.7 \%$ \\
6 & PT Indofarma (Persero) Tbk & $-2.59 \%$ & $3.3 \%$ \\
7 & PT Millennium Pharmacon In- & $7.14 \%$ & $15.4 \%$ \\
& ternational Tbk & & $38.9 \%$ \\
\hline
\end{tabular}

Source: Company's Financial Statement in Year 2016-2017

performance (Murat Ar and Baki, 2011). However, there is a research gap where other researchers revealed different conclusions. From a different perspective, Riyadi and Sumardi (2017) revealed that process innovation has a greater influence in improving the competitiveness of a company's business compared to other innovation strategies, namely product innovation and administrative innovation.

An empirical study conducted by Zehir et al. (2012) confirmed the positive relationship between TQM and innovation performance. Whereas Martínez-Costa et al. (2008) revealed different results, that TQM culture has a direct influence on improving the process and product design capabilities but does not affect product innovation. Other researchers' opinions support the negative relationship between TQM and innovation performance claimed that TQM can make organizations think narrowly and inhibit creativity because of the standardization practice (Zehir et al., 2012).

Meanwhile, Juran (2001) stated that one of TQM dimension, namely customer orientation has a significant positive relationship to innovation because customer focus can encourage companies to always meet the customer's needs and desires so that the company can survive in a competitive business environment. To clarify the issue in previous studies, the author is interested in conducting further investigation on the relationship between innovation strategy and TQM associated with business performance. One of the goals of this research is to contribute in an enriching way for the study of these variables to capture the current situation of the innovation strategy execution, TQM implementation, and business performance of the pharmaceutical industry in Indonesia today. This research is expected to be used as feedback for companies related to the execution of their innovation strategies and TQM implementation promptly to improve their competitive advantage, thus improving the company's business performance and creating sustainable growth.

\subsection{Innovation Strategy and TQM}

Innovation plays a very important role in providing unique products and services, creating value-added for the company, and defining entry barriers for new entrants. For this reason, innovation has triggered the interest of many researchers to iden- tify the drivers, and one of the issues that have been considered is whether the practice of TQM can emerge as one of the factors that influence the company's innovation strategy. In the current business context with global competition and high intensity of competitiveness, evaluation of business performance has become a very important element in the development of the organizational strategy. Performance evaluation can be defined as a process for measuring the efficiency and effectiveness of a production system. Thus, innovation strategy can have a positive effect on business performance. However, companies cannot obtain benefit from innovation if there is no organizational structure established to follow the strategy (Antunes et al., 2017).

Many researchers have revealed the results of empirical studies that the application of quality management has a positive relationship with innovation. The empirical study showed that this practice can train experts and specialists in research and development, create opportunities to apply these principles and quality management techniques in their innovation activities, thus they can find new target markets and potential customers, increase knowledge, and continue to improve their systems and work processes. Therefore, quality management practice toward innovation might help companies to improve their performance to satisfy customers, to minimize activities that do not create value-added, and reduce time and costs in developing new products (Kim et al., 2012).

Other studies have found that one of the key dimensions of TQM, which is customer orientation, has a significant impact to innovation. Customer orientation encourages organizations to fulfill customer needs and expectations consistently, so that the company can survive in a competitive environment in today's global market. In addition, continuous improvements made by the company is also important for the success of innovation through encouraging changes and creative thinking in generating new ideas. Zehir et al. (2012) found that all dimensions of TQM significantly give positive impact to innovation. An empirical study conducted by Zehir et al. (2012) confirmed the positive relationship between TQM and innovation performance. Whereas Miranda Silva et al. (2014) revealed different results, that the TQM culture has a direct influence on improv- 
ing the process and product design capabilities but does not affect product innovation. Other researchers' opinions support the negative relationship between TQM and innovation performance claimed that TQM can make organizations think narrowly and inhibit creativity because of the standardization practice (Martínez-Costa et al., 2008).

\subsection{Innovation Strategy and Business Performance}

Many studies revealed that innovation has played an important role in social and economic development and increases the competitiveness of companies. Innovation, like the terms used in business, are intended to describe new products, services, methods, and organizational approaches that enhance competitiveness of the company. The results of the Global Innovation survey conducted by the Boston Consulting Group (BCG) in 2014 revealed that innovation is the top 3 priority for three quarters of companies in the world. As many as $75 \%$ of respondents stated that investment in terms of innovation is primarily aimed at long-term benefits and the current competitive advantage that the company cares about (Wheelen et al., 2018).

Innovation strategy is a plan to increase market share or company profits through product and service innovation. When looking at innovation strategy through the eyes of the work that must be done, it appears that the strategy must be effective and correctly inform the executors of work, jobs, and which segments are targeted to achieve the highest growth, as well as unmet targets to give our customers better products. The innovation strategy, in the simplest terms, is to choose the most appropriate strategy among possible alternative options and develop the most appropriate type of action that is possible to be implemented at present (Al-Battaineh, 2018). The theory of innovation strategy stated that companies that have good business performance are constantly reviewing their products and services (their offerings), modifying their existing ones and developing something new in order to meet customers need better that previously unmet (David and David, 2017).

Previous studies regarding the role of innovation strategy on the company's business performance showed a positive relationship between them from various dimensions, for example Al-Battaineh (2018) revealed that product innovation, process innovation, and innovation management had a positive influence in improving the company's business performance. Other researchers, Beyene et al. (2016) explained that innovation strategy are positively related to product innovation performance. Whereas Riyadi and Sumardi (2017) revealed different perspectives that process innovation has a greater influence in increasing the competitiveness of a company's business compared to other innovation strategy, namely product innovation and administrative innovation. In addition, Antunes et al. (2017) argued that companies that adopt strategies of process innovation get improvements in their performance, both operationally and financially, while product innovation only provides improvements in the financial performance of organizations.

\subsection{TQM and Business Performance}

TQM is an integrated business management strategy aimed at instilling quality awareness in all company processes (Swink et al., 2014). The International Standards Organization (ISO) defines TQM as a management approach for an organization, which is quality-centered, based on the participation of all its members and aims at long-term success through customer satisfaction and benefits for all members of the organization and also for society (ISO 8402: 1994). Today, TQM can be a major factor in achieving competitive advantage for companies. This is because the TQM concept allows organizations to run the company efficiently, improve employee productivity, materials and also improve product quality (Martínez-Costa et al., 2008).

In the past few decades, as has been demonstrated through many publications, TQM has a significant role in improving business performance because it affects the growth and performance of the company so that the company continues to achieve continuous improvement as an important integral part of its organizational strategy (Jonah et al., 2018). The relationship between TQM and performance has been investigated by many researchers on various types of performance, including financial performance, operational performance and quality performance.

Although the effects of TQM on various types of performance are inconsistent, quality performance generally shows a strong and positive relationship (Zehir et al., 2012). According to Deming, quality is the main determinant of the company's success in a competitive business environment. Quality management is an activity that is increasingly important for all types of companies and is associated with corporate strategies to gain competitive advantage (López-Mielgo et al., 2009). Other researchers mentioned that some dimensions of TQM, especially those related to leadership and education, have a stronger correlation with business performance (Cetindere et al., 2014).

Thus, in this research, it is considered relevant the study of this issue since the study carried out previously showed contradictory results regarding relationship between innovation and TQM in business performance. The result of the study is expected to be used as feedback for companies related to the execution of their innovation strategies and TQM implementation promptly to improve their business performance. For academic interests, this research is expected to be used as empirical evidence regarding the influence of corporate innovation strategies and the implementation of TQM on business performance.

\subsection{Proposed Framework and Research Hypotheses}

The proposed framework in this study will focus on the business performance of the pharmaceutical industry in Indonesia which is related to innovation strategy and implementation of TQM based on literature and previous research are two important factors that plays an important role in supporting the company's performance where the two variables are correlated to improve the company's business performance.

In this research, the authors use the dimensions of product innovation, process innovation, administrative innovation and innovation management to measure innovation strategy. Those dimensions are based on previous research that product innovation and administrative innovation have a less significant influence on business performance so that it needs further investigation. Meanwhile, the constructs of TQM in the pharmaceutical 
industry in this study are leadership management, continuous improvement, management commitment, supplier quality, customer orientation, employee involvement, and quality management systems. The determination of the seven dimensions is based on previous research, including Zehir et al. (2012), Kumar and Prasad (2017), also the unit of analysis in this research is the pharmaceutical industry which has strict rules related to the production process and the products produced must meet GMP regulations which tend to still have weaknesses in those seven dimensions.

Business performance will be measured based on the performance of business functions. Business performance is defined as performance that is part of the company's business functions that support the company's overall performance based on four perspectives namely financial, customer, internal business processes and learning and growth. Therefore, the performance of business functions must be aligned with the performance of the company so that the company can meet predetermined targets. One of the most popular approaches for measuring business performance is the balanced scorecard (BSC). BSC can capture both financial element and non-financial strategies of the company and discuss causal relationships that can improve business results (Muiruri and Kilika, 2015). Robert Kaplan and David Norton developed this approach for the first time. To establish a company's future vision and provide a competitive advantage, financial data must be defined in intangible indicators (Lyibildire and Karasioglu, 2018).

Despite the previous studies showed the positive relationship between innovation strategy and TQM implementation, including Zehir et al. (2012). However, some researchers revealed different results, that TQM might be an inhibitor for innovation (Dinh et al., 2006). Therefore, it was considered relevant to investigate the relationship between innovation strategy and implementation of TQM. The study model is given in Figure 3.

Based on the model, three different hypotheses were formed:

$Q_{1}$ - Is there any relationship between innovation strategy and TQM implementation?

$H_{01}$ : There is no significant relationship between innovation strategy and TQM implementation.

$H_{1}$ : Innovation strategy and TQM implementation are interconnected with each other.

As described previously, several studies have shown innovation strategy gave a positive relationship to business performance (Al-Battaineh (2018) and Beyene et al. (2016). However, Riyadi and Sumardi (2017) revealed different perspectives that process innovation has a greater influence in increasing the competitiveness of a company's business compared to another innovation strategy.

Thus, it is considered relevant to the analysis of this relationship based on the following hypotheses:

$Q_{2}$ : What impact the adoption of innovation strategy might reflect on business performance?

$H_{02}$ : The adoption of an Innovation strategy does not have a positive influence on business performance

$\mathrm{H}_{2}$ : The adoption of innovation strategy encourages the improvement of business performance.

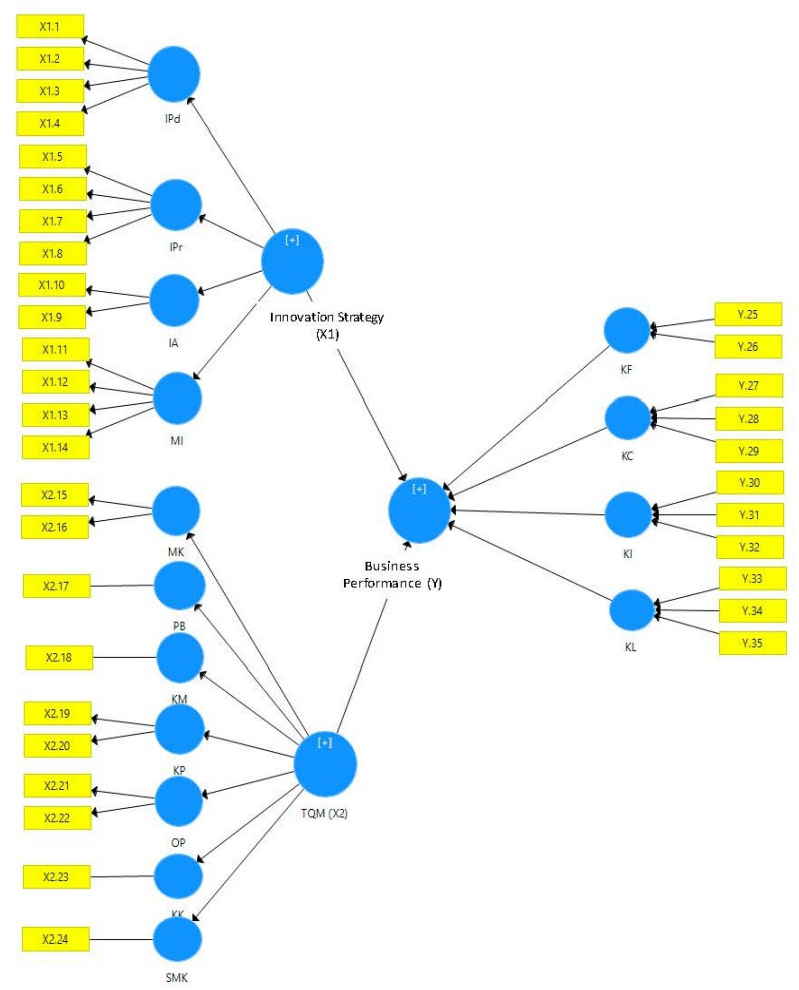

Figure 3: Model of research

Several studies were designed to investigate the relationship between TQM and business performance. Although the effects of TQM on various types of performance are inconsistent, quality performance generally shows a strong and positive relationship (Zehir et al., 2012). Other researchers revealed that TQM is positively associated with business performance such as financial and profitability (Nair and Choudhary, 2016). However, Cetindere et al. (2014) revealed a different perspective that dimensions of TQM related to leadership and education, have a stronger correlation with business performance compared to other dimensions. It is, therefore, necessary to analyze the relationship between TQM and business performance to clarify the issue, research hypotheses are defined as follows:

$Q_{3}$ - What impact TQM implementation might reflect on business performance?

$H_{03}$ : The implementation of TQM does not reveal an improvement in their business performance

$H_{3}$ : The implementation of TQM reveals an improvement in their business performance.

\section{METHODS}

This research is conducted at pharmaceutical companies in Indonesia and focused on the strategic management field that reviews the strategy of innovation and TQM implementation to improve the company's business performance. 
This research used a questionnaire survey method conducted during September-October 2019, through a descriptive and verification approach. The descriptive approach aims to obtain a description of the nature and characteristics of variables being studied related to the phenomenon happening in the object of study, to identify and analyze the relationships between variables. The verification research aims to test the hypothesis carried out through data collection (survey questionnaire). This study will be tested whether the innovation strategy and TQM have an influence on improving the business performance of pharmaceutical companies in Indonesia. Verification analysis was carried out using Partial Least Square Structural Equation Modeling (PLS-SEM). PLS is a method that can be used to analyze both reflective and formative constructs (Abdillah and Jogiyanto, 2015). In this study, business performance based on the balanced scorecard is a formative construct, while the innovation strategy and TQM are reflective constructs.

\subsection{Sampling Method}

The method of distributing questionnaires, using purposive sampling technique and quota sampling method, where nonrandom sampling previously determined by researchers with the following considerations: information needs for research and characteristics in the population. Sample criteria in this research are pharmaceutical companies in Indonesia that manufactured generic drugs and participated in providing drugs for JKN program. Quota sampling is set by determining sample represents at least fifty percent of the market share of the pharmaceutical industry that produced generic drugs and participated in providing drugs for the JKN program, the data obtained is expected to be relevant and represented the current situation of the pharmaceutical industry in Indonesia.

According to data from the Food and Drug Supervisory Agency and the Indonesian Ministry of Health, as of the second quarter of 2019 there were around 94 pharmaceutical companies producing generic drugs and participating as providers of drugs for the National Health Insurance Program (BPJS Kesehatan). Of these, 35 companies have market shares above $0.1 \%$, while the rest have market shares between $0.00 \%-0.09 \%$.

\subsection{Data Collection}

Hair et al. (2017) stated that the minimum use of samples in the Partial Least Square (PLS) analysis is based on (a) ten times the size of the most formative indicators used to measure one latent variable, or (b) ten times the highest number of structural paths directed at certain latent variables in the structural model. The structural path indicator in this study is 3 , thus the minimum PLS sample in this study is at least 30 companies.

The questionnaire was distributed using the online method. This method provided the benefit of being able to collect a lot of data in a short time.

Since this research measures the business performance based on business function, it is determined that respondents for each company are employees at the level of middle management to top management who are responsible for making decisions related to research variables, starting from assistant manager, section chief, manager, head of department, senior manager, general manager, and Director. Each company is represented by four respondents so that it is expected to be able to represent four perspectives of company performance based on a balanced scorecard, namely financial, customers, internal business processes, and learning growth.

\subsection{Measurement}

This research uses a 5 point rating scale, referring to the Likert Scale in general. The answers to each instrument with this Likert scale have gradations from very positive to very negative. The data obtained is then processed by the PLSSEM (Partial Least Square-Structural Equation Modeling) using SmartPLS 3.0 software. First, researchers develop a descriptive analysis of the items, followed by an analysis of causal relationships using path analysis to explain direct and indirect influence between variables and to investigate the influence through a path diagram of the causal relationship between independent variables on the dependent variable. In this study, the descriptive analysis of each variable is divided into 5 categories of measurement results with the percentage of respondents' answers as listed in the Table 2.

Following that, hypothesis test with the bootstrapping method to produce the statistical test used (t test). Significance value used is $\alpha=0.05$. Lastly, it is proceeded to a correlation analysis between the constructs on the level of dimensions and indicators of each variable studied in this research.

A strong correlation between constructs and the question items and a weak relationship with other variables is a way to test the construct validity. Construct validity consists of convergent validity and discriminant validity. Convergent validity is achieved if construct indicators have high correlations and have sufficient loading scores. Not only in loading scores, but validity is also shown by the convergence of all construct indicators. According to Vincenzo et al. (2010) the rule of thumb used for convergent validity is outer loading $>0.7,0.5$ and Average Variance Extracted (AVE) $>0.5$.

Meanwhile, according to Hair et al. (2017), the loading value $\geq 0.5$ is considered significant. Reliability tests are in line with construct validity used to measure the consistency of respondents in answering question items in questionnaires or research instruments (quantitative). We used composite reliability (CR) to measure reliability since it measures the true reliability value of a construct (Abdillah and Jogiyanto, 2015) According to Hair et al. (2017). Rule of thumb alpha value of Composite reliability must be greater than 0.7 although the value of 0.6 is still acceptable. For all the measures, both indices are higher than the evaluation criteria of 0.5 for the loading value and AVE and 0.7 for composite reliability (see Table 3 ).

As stated before, the business performance variable $(\mathrm{Y})$ is a formative construct. Parameters to assess its convergent validity using an outer weight of each indicator compared to one another to determine which indicator gives the biggest contribution in one construct and VIF (variance inflation factor) to 
Table 2: Interval value categories

\begin{tabular}{|c|c|c|c|}
\hline Range of Scores & $\begin{array}{l}\text { Innovation Strat- } \\
\text { egy }\left(X_{1}\right)\end{array}$ & TQM $\left(X_{2}\right)$ & $\begin{array}{l}\text { Business Perfor- } \\
\text { mance (Y) }\end{array}$ \\
\hline $1.00-1.79$ & Very Ineffective & Very bad & Very Low \\
\hline $1.80-2.59$ & Ineffective & $\mathrm{Bad}$ & Low \\
\hline $2.60-3.39$ & Quite effective & Fair & Fair \\
\hline $3.40-4.19$ & Effective & Good & High \\
\hline $4.20-5.00$ & Very effective & Very good & $\begin{array}{l}\text { Superior/ outstand- } \\
\text { ing }\end{array}$ \\
\hline
\end{tabular}

Table 3: PLS Test Parameter

\begin{tabular}{cl}
\hline Model Test & PLS-SEM Output \\
\hline \multirow{3}{*}{ Outer model (structural test) } & Convergent Validity (loading factor/ AVE/ outer weight, \\
& VIF) \\
& Discriminant Validity (Cross loading factor) \\
& Composite reliability \\
\hline \multirow{2}{*}{ Inner model (measurement test) } & R Square $\left(R^{2}\right)$ \\
& T statistic Test (estimated path coefficient) \\
\hline
\end{tabular}

Source: Abdillah $\mathcal{E}$ Jogiyanto, 2015

quantify the severity of multicollinearity between formative indicators. High correlation is not expected between formative indicators since the indicator's informative models are not interchangeable. VIF $<5$ indicates no critical levels of collinearity (Hair et al., 2017). Both outer weight and VIF value meets the specification (see Table ??)

Discriminant validity is achieved not only when the loading score meets the criteria but also indicated by correlation discrimination (cross-loading value), it means that each indicator loading should be greater than all of its cross-loadings. It is found that the value of the loading factor indicator for all intended indicators has the highest value compared to the value of the loading factor for the other dimensions. For example, the loading factor value of indicator Y.35 (for learning Growth dimension) has the highest loading factor value, which is 0.738 compared to the value of the other dimension loading factor. Thus, the value of the correlation indicator in a variable is better than the indicator for other variables, meaning that our research model meets discriminant validity.

The relationship between innovation strategy variables $\left(X_{1}\right)$ and TQM $\left(X_{2}\right)$ to the construct is a manifest indicator (reflective), whereas the relationship of business performance indicators $(\mathrm{Y})$ to the construct is a formative indicator and those were second-order construct / higher-order construct (HOC) model). One of the advantages of PLS compared to other analytical methods is being able to measure formative and reflective constructs in one research model. Previous researchers used several approaches to specify and estimate the reflective-formative higher-order construct (HOC) model in PLS-SEM, namely the repeated indicators approach and the two-stage approach (ex- tended repeated indicator approach). The results showed that the indicator repetition approach produced a smaller bias in estimating the higher-order construct measurement model, namely the relationship between the lower and higher-order components. In contrast, the two-stage approach shows better recovery parameters in path analysis 1) exogenous constructs to HOC, and 2) from HOC to endogenous constructs in the path model (Sarstedt et al., 2019).

To validate the overall model, the Goodness of Fit (GoF) parameter is used. GoF index is a single measurement used to validate the performance combination of the measurement model (outer model) and structural model (inner model). According to Abdillah and Jogiyanto (2015), the value of the GoF Index is derived from the roots of the average communalities index multiplied by the average of the R2 model. GoF values have a range between $0-1$, with a classification of small GoF values at 0.1 , moderate GoF at 0.25 , and a substantial GoF value at 0.36 .

\section{RESULTS AND DISCUSSION}

Based on questionnaire results received back from managers working in the pharmaceutical industry producing generic drugs and participating in providing drugs for the JKN program during September-October 2019 period, there were 42 pharmaceutical companies with a total of 168 respondents who filled the questionnaire and represented a total market share of generic drugs manufacturers of $77.15 \%$ which means have met the specified quota sampling requirements, which represent a minimum of $50 \%$ of the market share of the generic drug industry and a minimum of 30 companies. 
Table 4: Descriptive analysis result

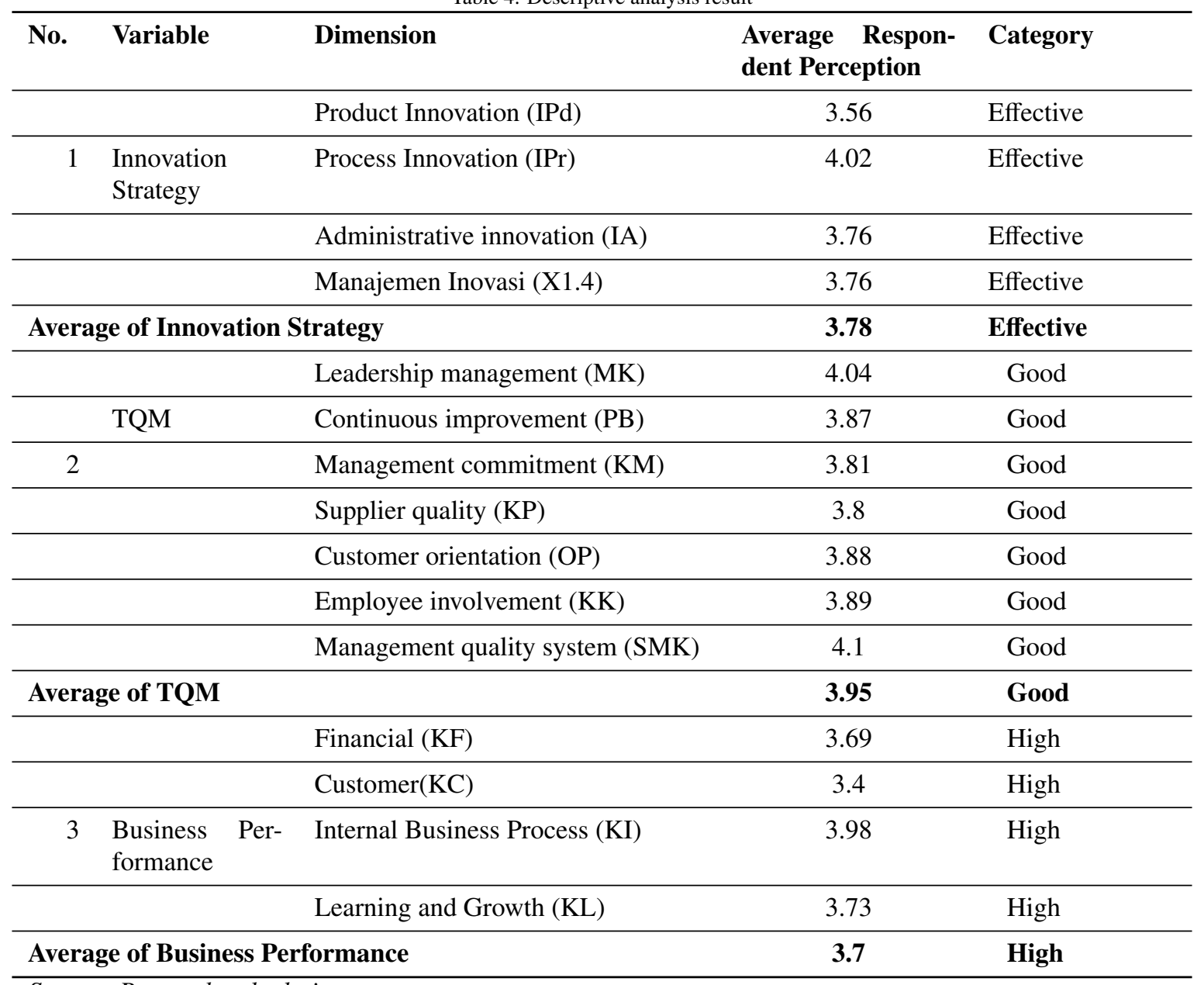

Source: Research calculations 
The result (see Table 4 shows that respondents' perceptions about innovation strategy viewed based on the dimensions of product innovation, process innovation, administrative innovation, and innovation management are in the effective category with an average value of 3.78. Respondents' perceptions related to the implementation of TQM which were assessed based on the dimensions of Leadership Management, Management Commitment, Supplier Quality, Customer Orientation, Continuous Improvement, Employee Involvement, and Quality Management System are well implemented (good category) with an average value of 3.95, whereas respondents' perceptions about business performance viewed based on the dimensions of financial, customer, internal business process and learning and growth performance are in the high category with average value 3.70. Table 5 is the result of the path coefficient analysis with the Higher Order Construct - standard repeated indicator approach.

The Table 5 is the result of the path coefficient analysis with the Higher-Order Construct - standard repeated indicator approach. $\mathrm{R}$ square is the best indicator of the explanatoriness degree of the regression model. Here, a $99.6 \%$ linear correlation was found between $\mathrm{R}$ square the dependent variable (business performance), and the independent variable (innovation strategy and TQM). This means that $99.6 \%$ of the business performance variable is explained by the innovation strategy and TQM variable.

Table 6 presents the correlation matrix of all variables. It shows a high degree of significant correlation between innovation strategy and TQM, innovation strategy and business performance, and TQM and business performance (correlation is significant at 0.05 level, $p$ values $; 0.05$, T statistics $i$ 1.96). The direction of the positive relationship is indicated by the positive original sample value. The significant correlation between innovation strategy, TQM and business performance confirms our study's hypotheses.

The present study sought to analyze the relationship between innovation strategy and TQM in improving the business performance of the Pharmaceutical Industry in Indonesia. Survey results show that the execution of innovation strategy is in the effective category with an average value of 3.78, TQM is well implemented (good category) with an average value of 3.95 , whereas business is in the high category with an average value of 3.70. This indicates that the pharmaceutical industry in Indonesia has good awareness in responding to business landscape changes since JKN implementation in 2014 which is to manufacture drugs with low cost and low margin.

In terms of our hypotheses (Table 6) findings for $H_{1}$ (Innovation strategy on TQM) confirm that implementation of the TQM system in a company interconnected with the Innovation strategy. This supports the findings of prior researches (Hung et al., 2011) that TQM implementation significantly gives a positive impact on innovation strategy in a company. One of the TQM dimensions, continuous improvement will provide an environment for the company to make innovation in order to meet customer needs and expectations.

The next results for hypothesis $H_{2}$ (Innovation strategy Business Performance) show that there is a positive correlation be- tween those variables in all dimensions. This finding aligns with previous studies regarding the role of innovation strategy on the company's business performance in various dimensions (Al-Battaineh (2018) and Antunes et al. (2017).

The further result shows that innovation management and product innovation give a bigger impact statistically (in terms of loading factor and R square) to innovation strategy compared to process innovation and administrative innovation. This proves the important role of innovation management in pharmaceutical companies in formulating corporate innovation strategies is in line with the company's vision and right on target. Some pharmaceutical companies in Indonesia have specialized departments that manage corporate innovation programs, called corporate planning strategy. The department's responsibilities include analyzing business trends (e.g changes in the company's strategic focus, merger acquisition opportunities), analyzing opportunities and threats both internal and external to develop new ideas, new products/services/processes, those are then used as work programs in the RD Department.

The results also support the findings of previous researchers (Simani and Kenyatta (2017), Simani and Kenyatta (2017), and Hassan et al. (2012)) who revealed clear evidence for the concept that companies that implemented TQM reveal an improvement in their business performance (in terms of financial and non-financial aspect). Leadership management (loading factor $=0.914$, R Square of 0.836 ) shows the biggest contribution to TQM implementation statistically. This proves that the role of the leader in the implementation of TQM is very important, one of the examples is in terms of communicating a quality culture to all employees in the company.

Several previous studies have been conducted and look into these dimensions, however, we believe the findings of this research formulate a number of important additions to the existing literature by fill a gap concerning some disagreements identified in previous investigations both of the ambiguity of the findings also concerning the different interpretations of the concepts studied. This research had the particularity to analyze the variable of innovation strategy in various dimensions, it was considered product innovation, process innovation, administrative innovation, and management innovation. Regarding the TQM, this research analyzed this variable through leadership management, continuous improvement, management commitment, supplier quality, customer orientation, employee involvement, and quality management systems. For business performance, this research analyzed this dimension based on the balanced scorecard concept, namely financial, customer, internal business process, and learning growth perspective. This research also provides a unique contribution to the analysis of the inter-dependencies between innovation strategy and TQM in improving business performance in Indonesian Pharmaceutical companies. Thus it will have strategic implications for the company and expect to be used as feedback related to the execution of their innovation strategies and TQM implementation promptly to improve their business performance. 
Table 5: Construct Measurement summary: Coefficient path analysis and Reliability (Innovation strategy and TQM)

\begin{tabular}{|c|c|c|c|c|c|}
\hline No & Construct & $\begin{array}{l}\text { Loading } \\
\text { factor }\end{array}$ & AVE & $\begin{array}{l}\text { Composite } \\
\text { Reliability }\end{array}$ & R Square \\
\hline \multicolumn{6}{|c|}{ Innovation Strategy $\left(X_{1}\right)$} \\
\hline 1 & Product Innovation (IPd) & 0.906 & 0.664 & 0.836 & 0.821 \\
\hline 2 & Process Innovation (Ipr) & 0.895 & 0.563 & 0.901 & 0.802 \\
\hline 3 & Administration innovation (IA) & 0.805 & 0.819 & 0.887 & 0.648 \\
\hline 4 & Innovation Management (MI) & 0.918 & 0.739 & 0.919 & 0.843 \\
\hline \multicolumn{6}{|c|}{$\mathbf{T Q M}\left(X_{2}\right)$} \\
\hline 1 & Management Commitment (KM) & 0.818 & 1.000 & 1.000 & 0.669 \\
\hline 2 & Supplier Quality (KP) & 0.743 & 0.731 & 0.844 & 0.552 \\
\hline 3 & Employee involvement (KK) & 0.703 & 1.000 & 1.000 & 0.495 \\
\hline 4 & Leadership Management (MK) & 0.914 & 0.822 & 0.902 & 0.836 \\
\hline 5 & Customer orientation (OP) & 0.830 & 0.674 & 0.805 & 0.688 \\
\hline 6 & Continuous improvement (PB) & 0.860 & 1.000 & 1.000 & 0.740 \\
\hline 7 & Quality Management system (SMK) & 0.802 & 1.000 & 1.000 & 0.363 \\
\hline \multicolumn{6}{|c|}{ R Square Business Performance $(Y)=99.6 \%$ (strong model) $;$ GoF Index $=0.690$ (Substantial) } \\
\hline
\end{tabular}

Table 6: Correlation Analysis (PLS-Bootsrapping's result)

\begin{tabular}{|c|c|c|c|c|c|}
\hline No & Variable correlation & $\begin{array}{l}\text { Original } \\
\text { Sample (O) }\end{array}$ & $\begin{array}{l}\text { Sample } \\
\text { Mean (M) }\end{array}$ & $\begin{array}{c}\text { T } \begin{array}{c}\text { Statistics } \\
(-O / S T D E V-)\end{array} \\
\end{array}$ & P Values \\
\hline 1 & Innovation Strategy (X1) à TQM (X2)* & 0.8180 & 0.8170 & 32.2970 & 0.000 \\
\hline 2 & Innovation Strategy à Business Performance $(\mathrm{Y})^{* *}$ & 0.4360 & 0.4400 & 7.1010 & 0.000 \\
\hline 3 & TQM (X2) à Business Performance (Y) & 0.4890 & 0.4850 & 7.1370 & 0.000 \\
\hline \multicolumn{6}{|c|}{$\begin{array}{l}* \text { Analysis using standard indicator approach } \\
* * \text { Analysis using Extended repeated indicator approach (two stage approach) } \\
\text { Two tailed test, level of significance }: 95 \%\end{array}$} \\
\hline
\end{tabular}




\section{CONCLUSION}

This study examines the relationship between innovation strategy, TQM and business performance. A proposed model comprises four types of innovation strategy, seven TQM practices, and four perspectives to measure business performance. To test the proposed model, data were collected from a sample of Indonesian pharmaceutical companies that represents at least fifty percent of the market share of the pharmaceutical industry that produced generic drugs and participated in providing drugs for the JKN program. The results of the analysis show that innovation strategies and TQM practices are interconnected and both innovation strategy and TQM can improve a company's business performance in all dimensions. In particular, the results indicate management innovation has the biggest contribution to the company's innovation strategy and leadership management has the biggest impact on TQM implementation.

Limitations of this study should be recognized to provide researchers with future research opportunities. First, respondents for this study are Indonesian pharmaceutical companies that manufactured generic drugs and participated in providing drugs for the JKN program. The firms fit the research purpose because they are affected by JKN implementation. However, other pharmaceutical firms, that did not manufacture generic drugs might have been left out of this study, whereas they could be more innovative. It would be promising to replicate this research using data collected from firms that produced both generic and branded products. Further, it may not be possible to generalize our findings for firms that are not manufactured generic products, since our data involves only generic manufacturers firms, the findings of this study may not be applicable to non-generic manufacturer firms. Future studies could be conducted to examine the relationship between innovation strategy and TQM practices in both generic product manufacturer firms and branded product manufacturer firms. Second, it would be worthwhile to consider conducting case studies to get an indepth insight on how innovative and TQM-driven firms improve their business performance and why management innovation is contributed the most important in executing innovation strategy and leadership management is the most important among TQM practices.

\section{References}

Abdillah, Jogiyanto, 2015. Partial Least Square (PLS) alternative Structural Equation Modelling (SEM) dalam Penelitian Bisnis. Penerbit Andi.

Ahmad, M. F., Zakuan, N., Jusoh, A., Takala, J., 2012. Relationship of TQM and Business Performance with Mediators of SPC, Lean Production and TPM. Procedia - Social and Behavioral Sciences 65, 186-191.

URL: https://doi.org/10.1016/j.sbspro.2012.11.109

Al-Battaineh, M. T., International Journal of Business and Management Invention (IJBMI) 2018. Effect of Innovation Strategies on the Functional Performance of SMEs Organizations in (Hassan Industrial City) 7 (5), 12-18. URL: http://www.ijbmi.org/v7i5 (version1).html

Antunes, M. G., Quirós, J. T., do Rosário Fernandes Justino, M., van der Wiele, T., 09 2017. The relationship between innovation and total quality management and the innovation effects on organizational performance. International Journal of Quality Reliability Management.

URL: https://doi.org/10.1108/IJQRM-02-2016-0025
Beyene, K. T., Shi, C., Wu, W. W., 2016. The Impact Of Innovation Strategy On Organizational Learning And Innovation Performance: Do Firm Size And Ownership Type Make a Difference? South African Journal of Industrial Engineering 27 (1), 125-136.

Cetindere, A., Duran, C., Yetisen, M., 2014. The effects of total quality management on the business performance: An application in the province of K"utahya. Procedia Economics and Finance 23, 1376-1382.

David, F. R., David, F. R., 2017. Strategic Management: A Competitive Advantage Approach, Concepts, 16th Edition. Pearson.

Dinh, T. H., Barbara, I., Tritos, L., 2006. The impact of total quality management on innovation: Findings from a developing country. International Journal of Quality Reliability Management 23 (9).

URL: https://doi.org/10.1108/02656710610704230 DOI: $10.1108 / 02656710610704230$

Hair, J. F., Hult, G., Ringle, C. M., Sarstedt, M., 2017. A Primer on Partial Least Square Structural Equation Modelling (PLS-SEM), 2nd Edición. SAGE Publications, Inc, Los Angeles.

Hassan, M., Malik, A., Faiz, M. F., 2012. An Empirical Assessment of Service Quality and its Relationship with Customer Loyalty Evidence from the Telecom Sector of Pakistan. International journal of Asian social science 2, 1647-1663.

URL: https://www . semanticscholar.org/paper/ An-Empirical-Assessment-of-Service-Quality-and-itsHassan-Malik/a58bcd3f920ad92ddc435de033c8e5d42a470877

Hung, R. Y. Y., Lien, B. Y.-H., Yang, B., Wu, C.-M., Kuo, Y.-M., 2011. Impact of TQM and organizational learning on innovation performance in the high-tech industry, journal = International Business Review 20 (2), 213-225.

URL: https://www.sciencedirect.com/science/article/pii/ S0969593110000855

DOI: https://doi.org/10.1016/j.ibusrev. 2010.07.001

Jonah, N., Ornguga, I. G., Torsen, E., 2018. The Effect of Total Quality Management (TQM) on the Organizational Growth of Adama Beverages: A Marketing Mix Perspective. International Journal of Science and Research (IJSR) 7 (7), 1096 - 1102.

URL: https://www.ijsr.net/get_abstract.php?paper_id= ART2019229

Juran, J. M., 2001. Section 4 The Quality Control Process - Excerpted from Juran's Handbook 5th edition. McGraw-Hill Companies.

Kalbe Farma, 2018. Kalbe farma annual report 2017.

URL: http://www.kalbe.co.id/Portals/0/pdf/annual-report/ KLBF_AR2017_FINAL.pdf

Kim, D.-Y., Kumar, V., Kumar, U., 2012. Relationship between quality management practices and innovation. Journal of Operations Management 30. URL: https://doi.org/10.1016/j.jom.2012.02.003 DOI: $10.1016 / j \cdot j o m .2012 .02 .003$

Kumar, V. K., Prasad, R. S., 2017. Total quality management practices in pharmaceutical industry: A study of selected companies in Andhra Pradesh and Telangana states. International Journal of Pharmaceutical science and Research 2 (6), 1-07.

Lyibildire, M., Karasioglu, F., 2018. Balanced scorecard in business performance measurement and its effect on financial structure. Global Journal of Management and Business Research: C Finance 18 (2), 14-21.

López-Mielgo, N., Montes-Peón, J. M., Vázquez-Ordás, C. J., 2009. Are quality and innovation management conflicting activities? Technovation 29 (8), 537-545.

URL: https://www.sciencedirect.com/science/article/pii/ S016649720900042X

DOI: https://doi.org/10.1016/j.technovation.2009.02.005

Martínez-Costa, M., Martínez-Lorente, A. R., Choi, T. Y., 2008. Simultaneous consideration of TQM and ISO 9000 on performance and motivation: An empirical study of Spanish companies. International Journal of Production Economics 113 (1), 23-39, research and Applications in E-Commerce and Third-Party Logistics Management Special Section on Meta-standards in Operations Management: Cross-disciplinary perspectives.

URL: https://www.sciencedirect.com/science/article/pii/ S0925527307003088

DOI: https://doi.org/10.1016/j.ijpe.2007.02.046

Miranda Silva, G., J. Gomes, P., Filipe Lages, L., Lopes Pereira, Z., 092014. The role of TQM in strategic product innovation: an empirical assessment. International Journal of Operations Production Management 34. 
URL: https://doi .org/10.1108/IJOPM-03-2012-0098

Muiruri, Z. K., Kilika, J., 2015. The Influence of the Balanced Score Card on Performance of Public Sector Organizations in Kenya. Science Journal of Business and Management 3 (5), 150-156.

Murat Ar, I., Baki, B., 04 2011. Antecedents and performance impacts of product versus process innovation. European Journal of Innovation Management 14.

$$
\text { URL: https : //doi.org/10.1108/14601061111124885 }
$$

Nair, G. K., Choudhary, N., 2016. Influence of critical success factors of total quality management on financial and non-financial performance of hospitality industry: an empirical study. International Journal of Productivity and Quality Management 17 (4).

URL: http: //www. inderscience.com/offer.php?id=75243

DOI: $10.1504 /$ I JPQM . 2016.075243

Riyadi, S., Sumardi, 2017. The Impact of Innovation Strategy toward Business Competitiveness of Manufacturing Industry in Surabaya, Indonesia. Hasanuddin Economics and Business Review 1 (1), 83-89.

URL: http://pasca.unhas.ac.id/ojs/index.php/hebr/article/ view/1159

Sarstedt, M., Hair, J. F., Cheah, J.-H., Becker, J.-M., Ringle, C. M., 62019. How to specify, estimate, and validate higher-order constructs in PLS-SEM.
Australasian Marketing Journal (AMJ)

URL: https : //doi .org/10.1016/j.ausmj . 2019.05.003

Simani, W. L., Kenyatta, J., 2017. TQM Perspectives under the Competitive Strategies and The Organization Performance in Kenyan Manufacturing Sector. Academy of Strategic Management Journal 16 (2).

Swink, M., Melnyk, S., Cooper, M. B., Hartley, J., 2014. Managing Operations Accross the Supply Chain. 2nd Edition. Mc Graw Hill/Irwin, New York, NY.

Tohidi, H., Jabbari, M. M., 2012. Product innovation performance in organization. Procedia Technology 1, 521-523.

URL: https://doi.org/10.1016/j.protcy.2012.02.112

Vincenzo, E. V., Chin, W. W., Henseler, J., Wang, H., 2010. Handbook of Partial Least Squares — How to Write Up and Report PLS Analyses. Vol. 10.1007/978-3-540-32827-8.

URL: http: //doi .org/10.1007/978-3-540-32827-8_29

DOI: $10.1007 / 978-3-540-32827-829$

Wheelen, T., Hunger, J., Hofmann, A., Bamford, C., 2018. Concepts in Strategic Management and Business Policy-Globalization, Innovation and Sustainability, global Edición. Pearson Education Ltd, Harlow-UK.

Zehir, C., Ertosun, O., Zehir, S. ., M"uceldilli, B., 2012. Total Quality Management Practices' Effects on Quality Performance and Innovative Performance. Procedia - Social and Behavioral Sciences 41 (2012), 273-280. 